\title{
Conventional PCR Detection and Real-Time PCR Quantification of Reniform Nematodes
}

Ronald J. Sayler, Department of Plant Pathology, University of Arkansas, Fayetteville 72701; Courtney Walker, University of Central Arkansas, Conway 72035; Fiona Goggin, Department of Entomology, University of Arkansas, Fayetteville 72701; Paula Agudelo, Clemson University, School of Agricultural, Forest, and Environmental Sciences, Clemson, SC 29634; and Terrence Kirkpatrick, Department of Plant Pathology, University of Arkansas, Fayetteville 72701

\begin{abstract}
Sayler, R. J., Walker, C., Goggin, F., Agudelo, P., and Kirkpatrick, T. 2012. Conventional PCR detection and real-time PCR quantification of reniform nematodes. Plant Dis. 96:1757-1762.

Reniform nematode (Rotylenchulus reniformis) is a relatively recent introduction into the continental United States that can cause major yield losses on a variety of important crops including cotton and soybeans. DNA sequences from the internal transcribed spacer (ITS) region of this nematode were used to design primers for conventional and real-time PCR, as well as a TaqMan probe. These primers amplified DNA of reniform nematode isolates from a wide geographic range

but did not detect genetically related species or other pathogenic nematodes found in production fields including Meloidogyne incognita and Heterodera glycines. Both SYBR green and TaqMan assays reliably quantified as little as $100 \mathrm{fg}$ of reniform nematode DNA, and could be used to quantify as few as five reniform nematodes. An inexpensive and rapid DNA extraction protocol for high throughput diagnostic assays is described.
\end{abstract}

Rotylenchulus reniformis is a phytopathogenic nematode with a host range of over 300 plant species in 77 families (22). This nematode is found in tropical, subtropical, and southern temperate zone soils $(15,23)$ in at least 38 countries around the world. In the southern United States, reniform nematode is a major nematode problem on cotton, causing an estimated loss in yield of $1.48 \%$ of the total U.S. crop $(213,627$ bales) in 2010 (4). The reniform nematode has surpassed root-knot (Meloidogyne incognita) as the most damaging pathogen of cotton in much of the southern United States (22). This pathogen is expanding its distribution range and increasing in population density in colonized fields. Reniform nematode populations can vary considerably throughout the southern United States and over time in the same locations (22). Genetic resistance is not currently available in commercial upland cotton varieties (21), although efforts are underway to develop resistant cultivars $(8,10,19,24,25)$. Current control methods rely on the application of nematicides or growing cotton in rotation with nonhost crops $(12,30,41,42)$ or tolerant varieties $(8,10,19,27-29,38)$. Transgenic resistance is also being explored as an alternative control method for this pathogen $(19,38)$.

Management of reniform nematodes relies on detection and quantification considerably in advance of planting so that growers can either apply nematicides or select appropriate crop rotation sequences. Therefore, growers need an accurate estimate of pathogen populations to make crop planting decisions. Every year, many public and private diagnostic clinics receive thousands of soil samples from growers needing accurate detection and quantification of population densities of reniform and other nematodes in fall-collected soil samples. Unfortunately, the current diagnostic method relies on physical extraction of nematodes from soil samples through one of several methods (9), combined with observation of the specimens via light microscopy for identification and counting. Not only does visual identification require considerable time for each sample, but specialized knowledge about the morphology of

Corresponding author: Ronald J. Sayler, E-mail: rjsayle@uark.edu

Accepted for publication 17 June 2012.

http://dx.doi.org/10.1094/PDIS-12-11-1033-RE

(C) 2012 The American Phytopathological Society this nematode is also required. Consequently, since the majority of diagnostic samples come in the fall immediately after harvest, diagnostic centers are often overwhelmed with samples and may take months to report nematode information back to growers.

The use of DNA-based techniques is becoming essential for government regulatory agencies where detection of quarantined microorganisms is vital. This technology is also being increasingly used by diagnostic laboratories in routine diagnosis of certain diseases. Polymerase chain reaction (PCR) is the extensively used nucleic acid-based pathogen detection technique because of its greater speed and sensitivity compared to restriction fragment length polymorphism (RFLP) and other non-nucleic acid techniques such as enzyme-linked immunosorbent assay (ELISA) or culturing (39). Conventional PCR is currently being used by many diagnostic laboratories because of its low cost and because the necessary equipment is routinely available in most plant pathology laboratories. Real-time PCR, although more expensive than conventional PCR, has the advantages of speed, sensitivity, and the ability to quantify pathogens. Real-time PCR is also superior to conventional PCR in terms of specificity and the ability to use TaqMan probes to develop multiplex assays that can screen for multiple pathogens at one time (39). Numerous PCR-based diagnostic assays have been developed for plant pathogenic nematodes, including members of the genera Meloidogyne $(3,20,26$, 33,35,46), Pratylenchus (45), Heterodera (18), Xiphinema $(2,40)$, Bursaphelenchus $(5,7,13,32)$, and Globodera $(14,16,17,37)$. The primary objective of this study was to develop a PCR-based detection method for reniform nematodes in order to provide extension specialists with a rapid and accurate alternative to visually identifying the presence or absence of this pathogen.

\section{Materials and Methods}

Nematode materials. The DNA from reniform nematode populations used for the development of real-time and conventional PCR assays was obtained from Arkansas cotton fields. Other nematode species used in this study, including Meloidogyne incognita and Heterodera glycines, were obtained from Arkansas cotton and soybean fields. All nematode samples used in this study are listed in Table 1.

PCR primer design. Reniform nematode specific primers and probes were manually designed by aligning numerous internal transcribed spacer (ITS) sequences obtained from over 50 reniform 
nematode accessions from Japan, China, Malaysia, and the United States through GenBank. The ITS sequences of Scutellonema truncatum and Globodera pallida were also included in the alignment to select regions unique to the reniform nematode, as the ITS sequences of these species were most similar to reniform nematode ITS sequences (1). Primers and probes specific to all reniform nematode ITS1 sequences, but different from related nematode genera, were designed manually after aligning the ITS sequences using ClustalW (34). All primer sequences were searched with blastn to confirm specificity to all reniform nematode ITS sequences in the GenBank. All primer and probe combinations were also verified to have low hetero- and homodimer potential using Oligoanalyzer 3.1 software (Integrated Technologies Inc.).

DNA extraction. Nematodes were isolated using Baermann funnel and sugar centrifugal flotation (9). For all real-time PCR assays, DNA was extracted from individual and multiple nematodes using the QIAamp DNA Micro Kit (Qiagen Inc.). DNA from individual reniform nematodes from different geographic locations used for primer specificity testing was extracted previously (1) using the Sigma REDExtract-N-Amp Tissue PCR Kit (SigmaAldrich Co.). The DNA for the multiplex assays was extracted from nematodes, isolated from soil as previously described, using

Table 1. Taxon, host, geographic origin, and Ren240 amplification of the nematodes used in this study

\begin{tabular}{lllc}
\hline Nematode species & Host & Geographic origin & $\begin{array}{c}\text { Ren240 } \\
\text { PCR }\end{array}$ \\
\hline Rotylenchulus reniformis & Cotton & Limestone, AL & + \\
Rotylenchulus reniformis & Cotton & Huxford, AL & + \\
Rotylenchulus reniformis & Banana & Columbia & + \\
Rotylenchulus reniformis & Tobacco & Columbia & + \\
Rotylenchulus reniformis & Cotton & Brazil & + \\
Rotylenchulus reniformis & Soybean & Brazil & + \\
Rotylenchulus reniformis & Sweet potato & Japan & + \\
Rotylenchulus reniformis & Sweet potato & Japan & + \\
Rotylenchulus reniformis & Eggplant & Honduras & + \\
Rotylenchulus reniformis & Cotton & St. Mathews, SC & + \\
Rotylenchulus reniformis & Cotton & Mississippi Co., AR & + \\
Rotylenchulus reniformis & Cotton & Baton Rouge, LA & + \\
Rotylenchulus reniformis & Cotton & Glendora, MS & + \\
Rotylenchulus reniformis & Cowpea & Ohahu, HI & + \\
Rotylenchulus reniformis & Cotton & Arkansas & + \\
Rotylenchulus parvus & Bentgrass & Arizona & - \\
Heterodera glycines & Soybean & Arkansas & - \\
Meloidegyne incognita & Cotton & Arkansas & - \\
\hline
\end{tabular}

a Parthenogenic population. All other populations were considered amphimictic. either the worm lysis buffer (43) or the rapid DNA extraction buffer (44). For the rapid DNA extraction protocol, a 50 - $\mu$ l bulk nematode aliquot was removed from the bottom of the sample of nematodes in water, isolated from soil as previously described. To these nematodes, $25 \mu \mathrm{l}$ of buffer A was added and the sample was heated to $95^{\circ} \mathrm{C}$ for $10 \mathrm{~min}$. Buffer A was made fresh for each extraction and consisted of $0.1 \mathrm{M}$ sodium hydroxide and $2 \%$ Tween 20. After the heating step, $50 \mu \mathrm{l}$ of buffer B, consisting of $0.1 \mathrm{M}$ Tris $\mathrm{HCl}$ and $2 \mathrm{mM}$ EDTA, was added to neutralize the extracted DNA solution. For determination of the presence of reniform nematode in native soils, bulk nematodes were isolated using Baermann funnel and sugar centrifugal flotation (9). For native soils, nematodes were isolated as described above and DNA was extracted from a $50-\mu \mathrm{l}$ bulk nematode sample in water using the rapid DNA extraction protocol.

Conventional and real-time PCR. All conventional PCR reactions were performed using the following conditions: $5 \times$ GoTaq Green Reaction Buffer (Promega Corp.), $200 \mu \mathrm{M}$ dNTP, $0.25 \mu \mathrm{M}$ forward and reverse primers, and 1 unit of Taq polymerase. Cycling conditions for Ren 240 primers was $95^{\circ} \mathrm{C}$ for 10 min followed by 35 cycles of $95^{\circ} \mathrm{C}$ for $15 \mathrm{~s}, 60^{\circ} \mathrm{C}$ for $30 \mathrm{~s}$, and $72^{\circ} \mathrm{C}$ for $60 \mathrm{~s}$. Multiplex reactions with universal nematode primers D2A and D3B (6) were performed under the same conditions except $55^{\circ} \mathrm{C}$ was used for annealing instead of $60^{\circ} \mathrm{C}$.

Real-time PCR was performed using 96-well low profile plates (USA Scientific), Quantifast SYBR green $2 \times$ master mix (Qiagen), and $0.25 \mu \mathrm{M}$ primer concentrations on a MX3000P qPCR thermocycler (Stratagene Corp.). The cycling conditions for Ren240 primers with SYBR green were as follows: $95^{\circ} \mathrm{C}$ for $10 \mathrm{~min}$ followed by 40 cycles of $95^{\circ} \mathrm{C}$ for $15 \mathrm{~s}, 60^{\circ} \mathrm{C}$ annealing for $30 \mathrm{~s}$, and $72^{\circ} \mathrm{C}$ extension for $30 \mathrm{~s}$; followed by melting curve analysis of $95^{\circ} \mathrm{C}$ for $1 \mathrm{~min}$; and $55^{\circ} \mathrm{C}$ for $30 \mathrm{~s}, 95^{\circ} \mathrm{C}$ for $15 \mathrm{~s}, 60^{\circ} \mathrm{C}$ for $30 \mathrm{~s}$, and $72^{\circ} \mathrm{C}$ for $60 \mathrm{~s}$. TaqMan PCR was performed using standard $10 \times$ PCR buffer with magnesium chloride, $200 \mu \mathrm{M}$ dNTP, $0.25 \mu \mathrm{M}$ forward $($ Ren $240 \mathrm{~F})$ and reverse (Ren240R) primers, $0.1 \mu \mathrm{M}$ probe (RenITS), and 1 unit of Taq polymerase. Cycling conditions for TaqMan PCR were identical to SYBR Green conditions except annealing was at $55^{\circ} \mathrm{C}$ for $30 \mathrm{~s}$. All assays were performed with three technical replications and all experiments were repeated. Standard curves of known reniform nematode DNA concentrations were constructed between the cycle threshold $(\mathrm{Ct})$ value and the $\log$ DNA concentration. The DNA concentration of the template was measured at $260 \mathrm{~nm}$ using a NanoDrop spectrophotometer (Thermo Scientific). For all Q-PCR reactions, nematode DNA was extracted using the Qiamp DNA micro kit (Qiagen). DNA was eluted from the column using $50 \mu \mathrm{l}$ of elution buffers, and $2 \mu \mathrm{l}$ of sample was used for Q-PCR.
1 Reniform
2 Reniform
3 Reniform
4 Reniform
5. S. truncatum
6. G. pallida
1. Reniform
2. Reniform
3. Reniform
4. Reniform
5. S. truncatum
6. G. pallida

Fig. 1. Country of origin and GenBank accession number are listed with the sequences as follows: Reniform 1, Japan, AY335191.1; 2, China, GU003959.1; 3, Malaysia, FJ374686.1; 4, U.S., AY373649.1; 5, Scutellonema truncatum, DQ316098.1; 6, Globodera pallida, GU084819.1. The representative sequence of 2 from China did not begin until $20 \mathrm{bp}$ after the 240-bp forward primer. The Ren240F and Ren240R primers are overlaid with arrows and highlighted in light gray. The RenlTS probe is overlaid with a bar and highlighted in dark gray. 


\section{Results}

DNA extraction. Both the worm lysis buffer (43) and the rapid DNA extraction (44) protocol worked equally well for PCR assays, although DNA was more amplifiable after 6 months when stored in the worm lysis buffers (data not shown). The rapid DNA extraction protocol was faster and used lower cost reagents than the worm lysis buffer.

Conventional PCR. Representative reniform nematode ITS sequences from each geographic location and ITS sequences from two nematodes species with the closest ITS sequences as determined by GenBank E Value score were determined (Fig. 1). All primer and probe combinations successfully detected reniform nematode DNA. The Ren 240 forward and reverse primers (Table 2) successfully amplified DNA from reniform nematodes from numerous geographical regions (Table 1), but not Heterodera glycines and Meloidogyne incognita, which could also commonly be present in production fields. The specificity of Ren 240 primers was further confirmed in a multiplex reaction with D2A and D3B universal nematode detection primers (Fig. 2). These universal primers amplified all nematode species DNA, confirming the presence of amplifiable DNA, while the Ren240 primers amplified only reniform nematode DNA. The identity of the 240-bp fragment amplified by these primers was confirmed to be from reniform nematode ITS by DNA sequence analysis. Analysis of native soil samples by both visual identification and conventional PCR showed that all samples found positive for reniform nematode were also found positive using PCR (Table 3). The presence of nematodes was confirmed by universal primers in all but one sample in which no nematodes were found by either microscopic inspection or PCR testing. All native soil samples found to have reniform nematodes by microscopic inspection were also positive for this pathogen using conventional PCR (Table 3).

Real-time PCR. Serial dilutions of reniform nematode DNA were accurately quantified using the Ren 240 forward and reverse primers with a high level of precision among technical replicates (Fig. 3A). As little as $100 \mathrm{fg}$ of DNA was detected and quantified using the Ren 240 primers in a SYBR green master mix (Fig. 3A). The correlation between cycle threshold $(\mathrm{Ct})$ value and the log of reniform nematode DNA concentration was 0.9925. Primer efficiency, calculated as 10(1/slope), was 2.00 . The SYBR green assay was also used to develop an empirical method for estimating reniform nematode numbers based on real-time PCR DNA quantification from a sample. Reniform nematode DNA was also quantified using a TaqMan probe with the Ren 240 primers at quantities as low as 1 pg (Fig. 3B). The correlation between $\mathrm{Ct}$ value and the log of reniform DNA concentration was 0.9928, and the efficiency of amplification with primers and TaqMan probe was 1.70 (Fig. 3B). Reniform nematodes were accurately quantified over a series of 5 , 10,25 , and 50 individuals using $2 \mu \mathrm{l}$ of the $50 \mu \mathrm{l}$ per sample of DNA extracted with the Qiamp DNA extraction kit, with a correlation between $\mathrm{Ct}$ value and number of reniform nematodes of $R^{2}=0.9557$ (Fig. 4).

\section{Discussion}

The Ren240 primers designed in this study were effective for specifically amplifying reniform nematode DNA in both SYBR green and TaqMan real-time PCR, as well as for conventional PCR. In addition, these Ren 240 primers were effectively multiplexed with the D2A and D3B universal primers, offering confirmation that DNA extraction produced DNA that was suitable for PCR. The utility of the Ren 240 primers was confirmed by the positive amplification of reniform nematode DNA extracted from specimens from a wide geographical range, suggesting that these primers should be suitable for molecular identification of reniform nematode specimens from around the world. The Ren240 bp primers and probes were homologous to all reniform nematode ITS sequences in GenBank, including a parthenogenic population from Japan (Accession AY335190.1), and were able to amplify DNA from this isolate as well as from all the amphimictic populations tested. The 240-bp fragment produced by the Ren $240 \mathrm{bp}$ primers is large enough to easily distinguish it from a primer dimer band on agarose gels and small enough for multiplexing with universal nematode primers for confirmation of DNA quality (Fig. 2). In

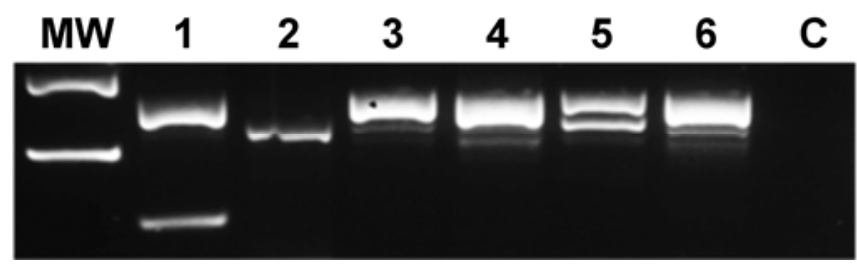

Fig. 2. Specificity testing of Ren240 primers in a multiplex reaction with D2B and D3A universal primers. Molecular weight marker (MW) lane contains a 1,000 base pair (BP) and a 500 bp band and the polymerase chain reaction (PCR) fragments in lanes $1-6$ bands at approximately $800 \mathrm{bp}$ and $240 \mathrm{bp}$. Lane contents are as follows: 1 , Reniform nematode (Rotylenchulus reniformis) (Arkansas); 2, Rotylenchulus parvus; 3, Heterodera glycines (Arkansas); 4, Meloidogyne incognita (Arkansas); 5, Heterodera glycines (Arkansas); 6, Heterodera glycines (Arkansas); C, No template control.

Table 3. Conventional polymerase chain reaction (PCR) detection of reniform nematodes isolated from native soils, visual identification as well as confirmation of nematode DNA by PCR using universal primers D2A and $\mathrm{D} 3 \mathrm{~B}$

\begin{tabular}{lcccc}
\hline $\begin{array}{l}\text { Sample } \\
\text { location }^{\text {a }}\end{array}$ & $\begin{array}{c}\text { Reniform } \\
\text { PCR }\end{array}$ & $\begin{array}{c}\text { D2A D3B } \\
\text { PCR }\end{array}$ & $\begin{array}{l}\text { Visual ID } \\
\text { reniform }\end{array}$ & $\begin{array}{c}\text { Visual ID } \\
\text { pathogenic } \\
\text { nematodes }\end{array}$ \\
\hline
\end{tabular}

SWREC 7

SWREC 2

SWREC 5

SWREC 6

SWREC 8

SWREC 1

SWREC 3

Soybean cyst

Desha Co. 8

Desha Co. 15

Turf 315

SWREC 4

Dallas Co. 1

-
-
+
+
+
-
+
-
-
+
+
+
+

$\begin{array}{lll}- & - & \\ + & - & \\ + & + & \\ + & + & \\ + & + & \\ + & - & \\ + & + & \\ + & - & \\ + & - & \\ + & + & \\ + & + & \\ + & - & \\ + & - & \end{array}$

a All samples were from native soils in Arkansas. Bulk nematode samples were isolated from soil sugar density centrifugation as described in Materials and Methods. SWREC refers to the southwest region extension center in Hope, AR, and Turf refers to soil samples taken from turfgrass.

Table 2. Sequence of primers and TaqMan probe used in this study

\begin{tabular}{|c|c|c|}
\hline Primer/Probe name & 5 to 3 ' sequence & $\mathbf{T m}^{\mathbf{a}}$ \\
\hline $\operatorname{Ren} 240 F^{b}$ & ACCGGCTTAATTGCAATGGT & 55.4 \\
\hline $\operatorname{Ren} 240 R^{b}$ & ACAACTGCTCAACAACGCAG & 56.3 \\
\hline $\mathrm{D} 2 \mathrm{~A}^{\mathrm{b}, \mathrm{c}}$ & ACAAGTACCGTGAGGGAAAGTTG & 57 \\
\hline $\mathrm{D} 3 \mathrm{~B}^{\mathrm{b}, \mathrm{c}}$ & TCGGAAGGAACCAGCTACTA & 54.9 \\
\hline RenITS $^{\mathrm{b}, \mathrm{d}}$ & FAM/CTTGAAACA/ZEN³/TCCAGTTTAAAGTGGCTGTTCGCC/Iowa black & 62.6 \\
\hline
\end{tabular}

\footnotetext{
a $\mathrm{Tm}$ represents the melting temperature at which $50 \%$ are annealed to the template.

${ }^{\mathrm{b}}$ Designed in this study.

${ }^{\mathrm{c}}$ Delay et al. (6).

${ }^{\mathrm{d}}$ Zen is an additional quencher proprietary to IDT Inc.
} 
addition to multiplexing with universal primers, multiplexing with primers specific to other nematode species is also possible, as long as the amplicons are of at least a 100-bp difference in size. The authors have successfully multiplexed the REN240 primers with primers for root-knot (M. incognita) and soybean cyst (H. glycines) nematodes isolated from native soils (data not shown).

When sequence diversity of ITS1 sequences from reniform nematode specimens around the world were compared, only a parthenogenic population from Japan exhibited significant sequence diversity (1). Leach et al. (11) proposed the reinstatement of $R$. nicotiana based on further studies on the genetic variability of these Japanese parthenogenetic isolates, and on Nakasono's (15) observations on their reproductive isolation from $R$. reniformis (11). Given that all other known reniform nematode populations around the world are amphimitic, the ITS1 sequence is ideal for use in molecular diagnostics, given its high copy number in the genome. Another report provided evidence for both a conserved set of ITS sequences in reniform nematode with no sequence diversity and a second paralogous set of ITS sequences in which sequence variation was found among isolates from the southern United States (36). These authors suggested that preferential amplification of the conserved ITS sequences was likely the reason that little ITS sequence variation has been found by Agudelo et al. (1) and in GenBank submissions from other authors. However, it is unclear how Tilahun et al. (36) were able to amplify and clone the more rare and variable ITS paralogs. The conserved ITS sequence is apparently more prevalent in the reniform nematode genome, as would be expected evolutionarily, and as evidenced from reniform nematode ITS sequences reported to GenBank. Given that the Ren240 primers matched all reniform nematode GenBank se-
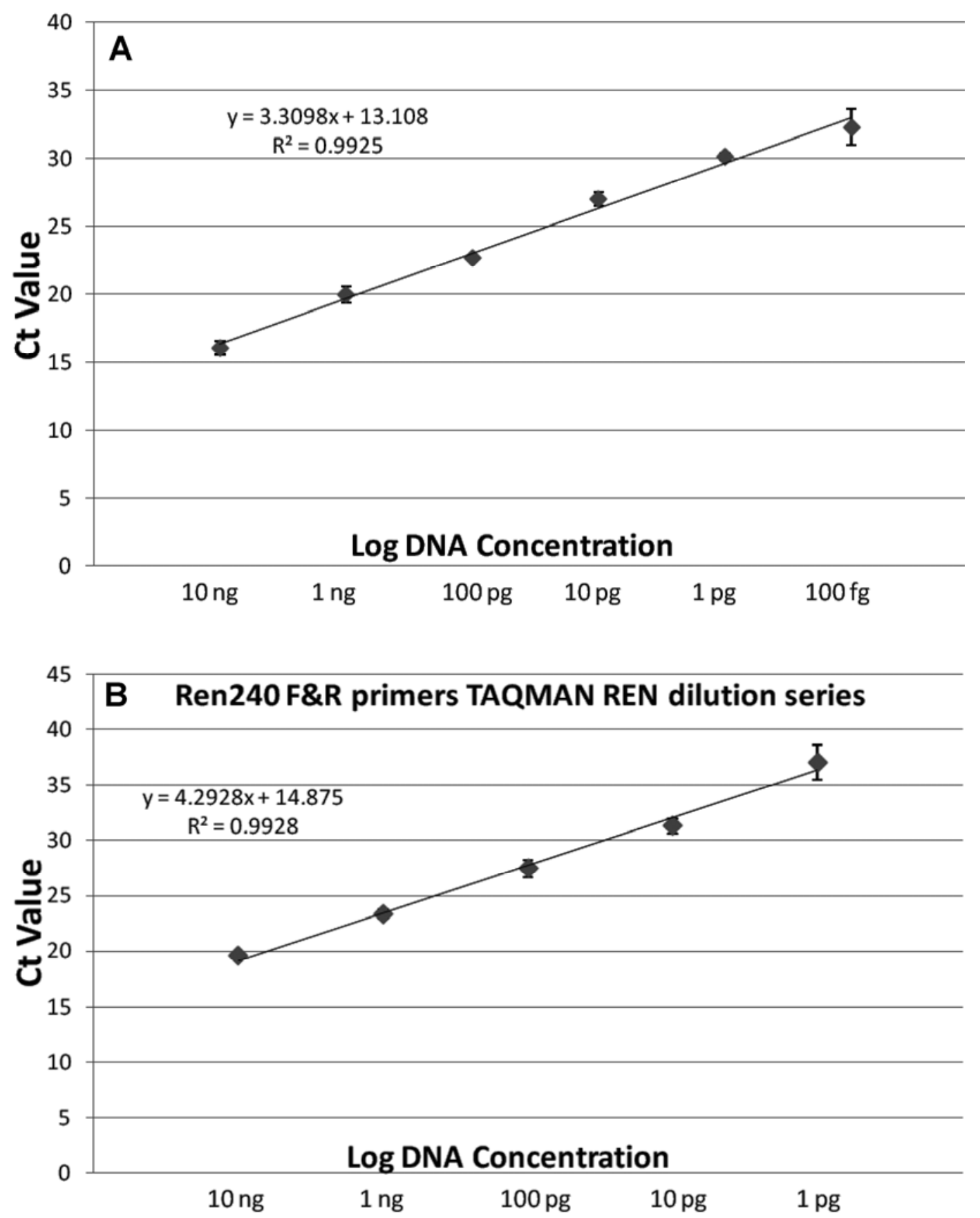

Fig. 3. Real-time polymerase chain reaction (PCR) fluorescence data from a dilution series of reniform nematode (Rotylenchulus reniformis) DNA. DNA concentrations represented on a log scale. A, SYBR green quantification of reniform nematode DNA using the Ren240F and Ren240R primers. B, TaqMan quantification of reniform nematode DNA using Ren240F and Ren240R primers and RenlTS probe. 
quences and the Ren240 primers amplified reniform nematode isolated from a diverse geographic range, this evidence strongly suggests that the PCR-based identification and quantification methods reported in this paper will be applicable to reniform nematode specimens around the world.

The advantage of the real-time PCR SYBR green and TaqMan assays developed in this study is their ability to quantify reniform nematode DNA and number of individuals. Currently, all methods of reniform nematode quantification involve direct visual observation and counting. Our real-time PCR techniques allow unbiased quantification of reniform nematode numbers based on extracted DNA from nematodes isolated by sugar density centrifugation. An unbiased DNA quantification method may be useful to scientists studying the host-pathogen interaction. A DNAbased method for quantifying reniform nematode numbers may also speed processing of large numbers of samples encountered by diagnostic labs, or by plant breeders selecting for resistant varieties. Real-time PCR methods also provide immediate results without the necessity of agarose gel electrophoresis. The SYBR green PCR method has the advantage of being less expensive than TaqMan when running a small number of reactions, but TaqMan is less expensive when running large numbers of samples. We found that the SYBR green protocol was almost tenfold more sensitive than TaqMan. This may be due to the fact that TaqMan has only one fluorescent molecule per amplicon, whereas numerous SYBR green dye molecules intercalate throughout the entire length of the amplicon. TaqMan has the advantage of greater specificity than SYBR green, as the probe provides an additional level of specificity. TaqMan quantification does not require melting curve analysis for the quantification of a single amplicon, as does SYBR green. TaqMan also provides capacity to multiplex reactions for different targets in the same reaction tube.

Both the conventional and real-time PCR methods developed in this report were effective in detection and quantification, respectively, of the reniform nematode. These DNA-based PCR detection methods may assist quarantine efforts to prevent the movement of this nematode to noninfested areas by rapidly and reliably identifying the pathogen. For routine diagnosis of reniform nematodes, an advantage of conventional PCR is that it requires only the most basic and least expensive laboratory equipment and less technical skill than for real-time PCR. In addition, this assay doesn't require the secondary step of digestion with restriction enzymes as required by some other nematode PCR diagnostic assays (31). Unfortunately, the results of the conventional PCR assay are strictly qualitative, so quantification of the nematodes in a sample would still require visual observation. However, the conventional PCR assay has been validated in detecting reniform nematodes from native soils. Although the conventional PCR assay reported here does not offer quantification, it could be very useful in presorting diagnostic samples rapidly. In this way, only those samples

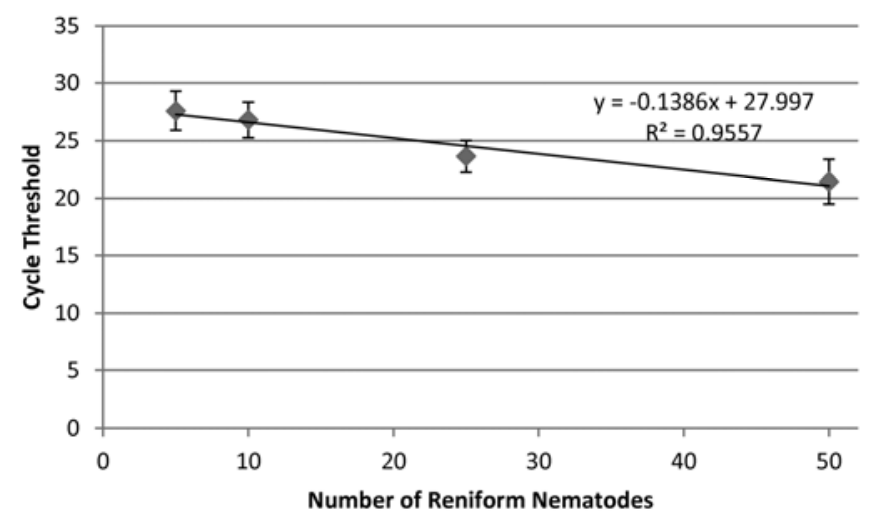

Fig. 4. Q-PCR quantification of reniform juveniles using SYBR green. The cycle threshold (Ct) number is graphed against the number of reniform nematodes used for DNA extraction. This experiment was performed using the Ren240 forward and reverse primers with SYBR green. containing the nematode would need to be visually quantified. Approximately $40 \%$ of soil samples submitted to the diagnostic laboratory have no significant plant pathogenic nematodes ( $T$. Kirkpatrick, personal communication). These samples require the most time to analyze because the diagnostician has to thoroughly look through them to ensure no pathogenic nematodes are present. Eliminating samples that are devoid of reniform nematodes should significantly decrease the time and labor that is currently required in diagnostic laboratories where all samples must be processed and inspected manually before a determination as to the presence or absence of the nematode can be made.

\section{Acknowledgments}

Funding for this work was provided in part through a grant from the Arkansas Soybean Promotion Board. The authors gratefully acknowledge Devany Crippen, Ronnie Bateman, and Robert Robbins for providing nematode identification expertise and nematode cultures, and David Meints for technical assistance.

\section{Literature Cited}

1. Agudelo, P., Robbins, R. T., Stewart, J. M., and Szalanski, A. L. 2005. Intraspecific variability of Rotylenchulus reniformis from cotton-growing regions in the United States. J. Nematol. 37:105-114.

2. Berry, S., Fargette, M., Morand, S., and Cadet, P. 2007. Reliability of PCR based techniques for detection and discrimination of plant-parasitic nematodes of sugarcane. Nematology 9:499-514.

3. Berry, S. D., Fargette, M., Spaull, V. W., Morand, S., and Cadet, P. 2008. Detection and quantification of root-knot nematode (Meloidogyne javanica), lesion nematode (Pratylenchus zeae) and dagger nematode (Xiphinema elongatum) parasites of sugarcane using real-time PCR. Mol. Cell. Probe. 22:168-176.

4. Blasingame, D. C., and Patel, M. V. 2011. Cotton disease loss estimate committee report. Pages 306-308 in: Proceedings of the 2011 Beltwide Cotton Conferences, Atlanta, GA.

5. Cao, A. X., Liu, X. Z., Zhu, S. F., and Lu, B. S. 2005. Detection of the pinewood nematode, Bursaphelenchus xylophilus, using a real-time polymerase chain reaction assay. Phytopathology 95:566-571.

6. DeLey, P., F'elix, M. A., Frisse, L. M., Nadler, S. A., Sternberg, P. W., and Thomas, W. K. 1999. Molecular and morphological characterisation of two reproductively isolated species with mirrorimage anatomy (Nematoda: Cephalobidae). Nematology 2:591-612.

7. Francois, C., Castagnone, C., Boonham, N., Tomlinson, J., Lawson, R., Hockland, S., Quill, J., Vieira, P., Mota, M., and Castagnone-Sereno, P. 2007. Satellite DNA as a target for TaqMan real-time PCR detection of the pinewood nematode, Bursaphelenchus xylophilus. Mol. Plant Pathol. 8:803809.

8. Gutierrez, O. A., Robinson, A. F., Jenkins, J. N., McCarty, J. C., Wubben, M. J., Callahan, F. E., and Nichols, R. L. 2011. Identification of QTL regions and SSR markers associated with resistance to reniform nematode in Gossypium barbadense L. accession GB713. Theor. Appl. Genet. 122:271-280

9. Jenkins, W. R. 1964. A rapid centrifugal-flotation technique for separating nematodes from soil. Plant Dis. Rep. 48:692.

10. Koenning, S. R., Barker, K. R., and Bowman, D. T. 2000. Tolerance of selected cotton lines to Rotylenchulus reniformis. J. Nematol. 32:519-523.

11. Leach, M., Agudelo, P., and Lawton-Rauh, A. 2012. Genetic variability of Rotylenchulus reniformis. Plant Dis. 96:30-36.

12. Leach, M. M., Agudelo, P., and Lawton-Rauh, A. 2009. Effect of crop rotation on Rotylenchulus reniformis population structure. J. Nematol. 41:347-348.

13. Leal, I., Green, M., Allen, E., Humble, L., and Rott, M. 2007. Application of a real-time PCR method for the detection of pine wood nematode, Bursaphelenchas xylophilus, in wood samples from lodgepole pine. Nematology 9:351-362.

14. Madani, M., Subbotin, S. A., and Moens, M. 2005. Quantitative detection of the potato cyst nematode, Globodera pallida, and the beet cyst nematode, Heterodera schachtii, using Real-Time PCR with SYBR green I dye. Mol. Cell. Probe. 19:81-86.

15. Nakasono, K. 2004. Studies on morphological and physio-ecological variations of the reniform nematode, Rotylenchulus reniformis Linford and Oliveira, 1940 with an emphasis on differential geographical SSR markers for Rotylenchulus reniformis: Distribution of amphimictic and parthenogenic populations in Japan. J. Nematol. 36:356-420.

16. Nakhla, M. K., Owens, K. J., Li, W. B., Wei, G., Skantar, A. M., and Levy, L. 2010. Multiplex real-time PCR assays for the identification of the potato cyst and tobacco cyst nematodes. Plant Dis. 94:959-965.

17. Nowaczyk, K., Dobosz, R., Kornobis, S., and Obrepalska-Steplowska, A. 2008. TaqMan REAL-Time PCR-based approach for differentiation between Globodera rostochiensis (golden nematode) and Globodera artemisiae species. Parasitol. Res. 103:577-581.

18. Ou, S., Peng, D., Liu, X., Li, Y., and Moens, M. 2008. Identification of Heterodera glycines using PCR with sequence characterised amplified 
region (SCAR) primers. Nematology 10:397-403

19. Parkhi, V., Kumar, V., Campbell, L. M., Bell, A. A., Shah, J., and Rathore, K. S. 2010. Resistance against various fungal pathogens and reniform nematode in transgenic cotton plants expressing Arabidopsis NPR1. Transgenic Res. 19:959-975.

20. Qiu, J. J., Westerdahl, B. B., Anderson, C., and Williamson, V. M. 2006. Sensitive PCR detection of Meloidogyne arenaria, $M$. incognita, and $M$. javanica extracted from soil. J. Nematol. 38:434-441.

21. Robinson, A., ed. 1999. Cotton: Origin, history, technology, and production. JohnWiley \& Sons, New York.

22. Robinson, A. F. 2007. Reniform in US cotton: When, where, why, and some remedies. Annu. Rev. Phytopathol. 45:263-288.

23. Robinson, A. F., Inserra, R. N., Caswell-Chen, E. P., Vovlas, N., and Troccoli, A. 1997. Rotylenchulus species: Identification, distribution, host ranges, and crop plant resistance. Nematropica 27:127-180.

24. Romano, G. B., Sacks, E. J., Stetina, S. R., Robinson, A. F., Fang, D. D., Gutierrez, O. A., and Scheffler, J. A. 2009. Identification and genomic location of a reniform nematode (Rotylenchulus reniformis) resistance locus (Ren (ari)) introgressed from Gossypium aridum into upland cotton $(G$. hirsutum). Theor. Appl. Genet. 120:139-150.

25. Romano, G. B., Sacks, E. J., Stetina, S. R., Robinson, A. F., Fang, D. D., Gutierrez, O. A., and Scheffler, J. A. 2009. Reniform nematode (Rotylenchulus reniformis) resistance locus from Gossypium aridium identified and introgressed into upland cotton (G. Hirsutum). J. Nematol. 41:375376.

26. Saeki, Y., Kawano, E., Yamashita, C., Akao, S., and Nagatomo, Y. 2003. Detection of plant parasitic nematodes, Meloidogyne incognita and Pratylenchus coffeae by multiplex PCR using specific primers. Soil Sci. Plant Nutr. 49:291-295.

27. Shannon, J. G., Lee, J. D., Wrather, J. A., Sleper, D. A., Mian, M. A. R., Bond, J. P., and Robbins, R. T. 2009. Registration of S99-2281 soybean germplasm line with resistance to frogeye leaf spot and three nematode species. J. Plant Reg. 3:94-98.

28. Starr, J. L., Smith, C. W., Ripple, K., Zhou, E., Nichols, R. L., and Faske, T. R. 2011. Registration of TAM RKRNR-9 and TAM RKRNR-12 germplasm lines of upland cotton resistant to reniform and root-knot nematodes. J. Plant Reg. 5:393-396.

29. Stetina, S. R., Sciumbato, G. L., Blessitt, J. A., and Young, L. D. 2006. Cotton cultivars tolerant to reniform nematode. J. Nematol. 38:294.

30. Stetina, S. R., Young, L. D., Pettigrew, W. T., and Bruns, H. A. 2007. Effect of corn-cotton rotations on reniform nematode populations and crop yield. Nematropica 37:237-248.

31. Szalanski, A. L., Sui, D., Harris, T. S., and Powers, T. O. 2001. Identification of cyst nematodes of agronomic and regulatory concern with PCR-RFLP of ITS1. J. Nematol. 33:191-194.

32. Takeuchi, Y., Kanzaki, N., and Futai, K. 2005. A nested PCR-based method for detecting the pine wood nematode, Bursaphelenchus xylophilus, from pine wood. Nematology 7:775-782.
33. Tesarova, B., Zouhar, M., and Rysanek, P. 2003. Development of PCR for specific determination of root-knot nematode Meloidogyne incognita. Plant Prot. Sci. 39:23-28.

34. Thompson, J. D., Higgins, D. G., and Gibson, T. J. 1994. CLUSTAL W: Improving the sensitivity of progressive multiple sequence alignments through sequence weighting, position specific gap penalties and weight matrix choice. Nucleic Acids Res. 22:4673-4680.

35. Tigano, M., de Siqueira, K., Castagnone-Sereno, P., Mulet, K., Queiroz, P., dos Santos, M., Teixeira, C., Almeida, M., Silva, J., and Carneiro, R. 2010. Genetic diversity of the root-knot nematode Meloidogyne enterolobii and development of a SCAR marker for this guava-damaging species. Plant Pathol. 59:1054-1061

36. Tilahun, Y., Soliman, K., Lawrence, K. S., Cseke, L. J., and Ochieng, J. W. 2008. Nuclear ribosomal DNA diversity of a cotton pest (Rotylenchulus reniformis) in the United States. Afr. J. Agric. Res. 7:3217-3224.

37. Toyota, K., Shirakashi, T., Sato, E., Wada, S., and Min, Y. Y. 2008 Development of a real-time PCR method for the potato-cyst nematode Globodera rostochiensis and the root-knot nematode Meloidogyne incognita. Soil Sci. Plant Nutr. 54:72-76.

38. Urwin, P. E., Levesley, A., McPherson, M. J., and Atkinson, H. J. 2000. Transgenic resistance to the nematode Rotylenchulus reniformis conferred by Arabidopsis thaliana plants expressing proteinase inhibitors. Mol. Breed. 6:257-264.

39. Vincelli, P., and Tisserat, N. 2008. Nucleic acid-based pathogen detection in applied plant pathology. Plant Dis. 92:660-669.

40. Wang, X. R., Bosselut, N., Castagnone, C., Voisin, R., Abad, P., and Esmenjaud, D. 2003. Multiplex polymerase chain reaction identification of single individuals of the longidorid nematodes Xiphinema index, $X$ diversicaudatum, $X$-vuittenezi, and $X$-italiae using specific primers from ribosomal genes. Phytopathology 93:160-166.

41. Westphal, A., and Scott, A. W. 2005. Implementation of soybean in cotton cropping sequences for management of reniform nematode in South Texas. Crop Sci. 45:233-239.

42. Westphal, A., and Smart, J. R. 2003. Depth distribution of Rotylenchulus reniformis - Under different tillage and crop sequence systems. Phytopathology 93:1182-1189.

43. Williams, B., Schrank, B., Huynh, C., Shownkeen, R., and Waterston, R. 1992. A genetic mapping system in Caenorhabditis elegans based on polymorphic sequence-tagged sites. Genetics 131:609-624.

44. Xin, Z., Velten, J. P., Oliver, M. J., and Burke, J. J. 2003. High-throughput DNA extraction method suitable for PCR. BioTechniques 34:820-826.

45. Yan, G., Smiley, R. W., Okubara, P. A., Skantar, A., Easley, S. A., Sheedy, J. G., and Thompson, A. L. 2008. Detection and discrimination of Pratylenchus neglectus and P. thornei in DNA extracts from soil. Plant Dis 92:1480-1487.

46. Zijlstra, C., van Hoof, R., and Donkers-Venne, D. 2004. A PCR test to detect the cereal root-knot nematode Meloidogyne naasi. Eur. J. Plant Pathol. 110:855-860. 